\title{
CHARACTERIZATION OF NEW BIOTYPES OF P157 STRAIN OF Metarhizium anisopliae var. anisopliae, GOT BY TREATMENT WITH GAMMA RADIATION
}

\author{
(Caracterización de nuevos biotipos de la cepa P157 de Metarhizium anisopliae \\ var. anisopliae obtenidos por tratamiento con radiación gama)
}

\author{
Minancy Gomes de Oliveira* \\ Neiva Tinti de Oliveira \\ Elza Áurea de Luna Alves Lima \\ Departamento de Micología - Centro de Ciencias Biológicas \\ Universidade Federal de Pernambuco-50670-420-Recife-PE-Brasil
}

Palabras clave: Metarhizium anisopliae, radiación gama, biotipos

Key words: Metarhizium anisopliae, gamma radiation, biotypes

\section{RESUMEN}

Conidios de lacepa silvestre P157 de Mctarhizium anisopliae var: anisopliae (1. .etsch.) Sorokin, fueron expuestos a la radiación gama para la obtención de nuevos biotipos. En la dosis de 390Gy se obtuvo 36 colonias (MaP). Cinco colonias (MaP 03, MaP 17, MaP 25, MaP 27), expresaron alteración morfológica para el color en el Medio Completo. En este, 21 colonias presentaron crecimiento micelial significativamente distinto del testigo silvestre, después de 12 dias de la inoculación. La colonia MaP 25, presentó mayor valor de crecimiento micelial y la colonia M:aP 11, el menor valor. Entre las colonias obtenidas, solamente la colonia MaP 28 presentó auxotrofia, identificada como una deficiencia en la sintesis del ácido paraminobenzóico. Los conidios de 29 colonias, presentaron un promedio de porcentaje de germinación significativamente destinto del respectivo aislamiento silvestre, después de 12 horas de incubación en Medio Minimo, a $25^{\circ} \mathrm{C}$. Las colonias MaP $02, \mathrm{MaP} 21$ $y$ MaP 36 , presentaron precocidad en la germinación de los conidios en relación al patrón silvestre.

\section{INTRODUCTION}

Some fungi reveal great possibilities of being used in insect and pest biological control programmes because they have an entomopathogenic action. Among these, $\boldsymbol{M}$. anisopliae is one of the most studied as regards the pathogenicity and virulence on more than 200 species of insects,

\section{SUMMARY}

Conidia of the wild P157 strain Metarhizium anisopliae var.anisopliae (A.tetsch.), were exposed to gamma radiation to obtain new biotypes. At a dose of $390 G y, 36$ colonies (A faP) were obtained. Five colonies (MaP 03, MaP 17, MaP 25, MaP 27 and MaP 29) showed morphological alteration to colour in the Complete Medium. In this same medium, 21 colonies showed a significantly different mycelial growth from the wild strain after 12 days of innoculation. The MaP 25 colony showed the greatest value of mycelial growth, and the MaP 11 colony, the least value. Among the colonies obtained, only MaP 28 showed auxotrophy, identified as a deficiency in the synthesis of the paraminobenzoic acid. Conidia of twentynine colonies exhibited an average germination percentage significantly different from the wild strain after a twelve hour incubation in Minimum Medium, at $25^{\circ} \mathrm{C}$. The MaP 02, MaP 21 and MaP 36 colonies showed some precocity in conidial germination as regards the wild strain.

being many of then of agronomic interest $(2,3,17,25,35)$. Two characteristics associated with this fungus are of great relcvance for its use in the field as a biocontrol agent: it docs not mean pathogenicity for man and it be obtained in large quantitics at a relatively low cost (27).

In Brazil, M.anisopliae has been used very successfully in the biologic control of sugar-cane cicadas

\footnotetext{
* Part of a dissertation to obtain a Ms. degree in Criptogams at the Universidade Federal de Pernambuco, Recife, PE, Brazil.
} 
(Mahanarva posticata Stal,, Mahanarva fimbriolata Stal.) and those of pastures Deois flavopicta Stal. and Zulia entreriana Berg. This fungus is also used in the control of Diatraea saccharalis Fabr, Hypothenemus hamppei Ferrar, Tibraca limbativentris Stal. and Cornitermes cumblans $\operatorname{Kollar}(2,7,13,34)$.The efficiency of entomopathogenic fungi used in biological control, can be improved by means of genetic manipulation, by altering. among other things, factors like sporulation, dispersion and tolerance of the spores to stress (36). A considerable increase in the infectivity of a wild strain of $\boldsymbol{M}$. anisopliae was obtained by Yokoyama et al. (37) after treatment of protoplasts with UV light. Tsai et al. (36) isolated samples of M. anisopliae resistant to Benomyl and Carbendazim after treatment of conidia with UV. characteristics which are desirable in integrated past control programmes. The identification of the traces which determine pathogenicity and virulence is a fundamental step for the improvement of these fungi. Riba et al. (26), point out that the virulence of a strain seems to be the result of the manifestation of different genes. Among the various factors related to virulence are the speed in germination of the conidia, production of extra-cellular enzymes related to penetration (lipases, proteases and quitinases) and production of toxins $(1,6,23,29,31,32)$. The speed in germination of the conidia and the formation of appressoria are crucial events in pathogenesis (9). Resistance to high temperatures and UV radiation, $\mathrm{pH}$, luminosity, nutritional sources, colony and stock age are factors which act on the viability and speed germination of the conidia of entomopathogenic fungi $(8,11,15,18,30)$. The objectives of this study were the produciion of new biotypes of $\boldsymbol{M}$. anisopliae var. anisopliae using gamma radiation, through the analysis of mycelial growth, auxotrophy, conidia germination, and morphological and physiological characterization.

\section{MATERIALS AND METHODS}

The P157 strain of $\boldsymbol{M}$. anisopliae var, anisopliae used was granted by the culture collection (Micoteca URM), of the Department of Mycology of the Federal University of Pernambuco, Brazil; this strain was isolated from Mahanarva posticata Stal., and maintained in solid Complete Medium (MC) (24), modified by Azevedo and Costa (5).

Conidia from colonies of 8-day old monosporic cultures (12), were separately suspended in $3 \mathrm{ml}$ of Tween $80(0,1 \% \mathrm{v} / \mathrm{v})$ solution and disaggregated in a vortex agitator. Appropriate $(1: 10)$ dilutions were made and distributed to five test tubes, each containing $5 \mathrm{ml}$ of suspension with $10^{6}$ conidia/ml, estimated quantitatively in a Neubauer Chamber. The suspensions were submitted to different doses of gamma radiation Cobalt 60 type
GAMMABEAN 650 - Atomic Energy of Canada, (50, 100,150 and $200 \mathrm{~Gy}$ ). One of the suspensions not treated with radiation was used as a control. After this procedure, the suspensions were proportionally diluted $(1: 10)$ in a saline solution $(0,85 \% \mathrm{v} / \mathrm{v})$ up to a concentration of $10^{2}$ conidia/ml. They were placed in triplicates on Petri dishes containing solid $\mathrm{MC}$ and $0,1 \mathrm{ml}$ of these suspensions was spread with a Drigalsky ring and then incubated at $25^{\circ} \mathrm{C}$ for 48 hours. After the incubation period, the surviving colonies were counted, taking into consideration the number of colonies obtained in the control as a $100 \%$ survival. Data obtained served as a basis for constructing a survival curve and for calculating the dose necessary to obtain $5 \%$ survival by means of linear regression.

A suspension of conidia with $10^{6}$ conidia/ml was submitted to a dose of gamma radiation of $390 \mathrm{~Gy}$, aiming at a survival rate lesser than $5 \%$. The suspension was diluted proportionally $(1: 10)$ to a concentration of $10^{2}$ conidia/ml and aliquots of this suspension were placed on 10 Petri dishes containing solid MC. The dishes were incubated for 48 hours at $25^{\circ} \mathrm{C}$. The colonies arising were transferred to test tubes containing solid MC and incubated at room temperature and luminosity for 8 days. These colonies were designated as MaP.

The micromorphologic characters were analyzed by means of smearing conidia separately on Petri dishes containing solid $\mathrm{MC}$ at three different points and covering them with cover glass. The dishes were incubated for five days at $25^{\circ} \mathrm{C}$. The cover glass was removed from the cultures and placed on slides with a drop of Amann blue, and observed under light microscope.

For the analysis of the macroscopic characters, 7 day-old mycelium discs from the MaP colonies, cut with the aid of a $5 \mathrm{~mm}$ diameter cork drill, were transferred separately to the center of the Petri dishes containing solid $\mathrm{MC}$, in triplicates, with the help of a platinum ring, and then, incubated at $25^{\circ} \mathrm{C}$. Growth was accompanied for a period of 12 days with observation intervals on the 6 th, 9 th and 12 th days. In this process the colour and diameter parameters of the colonies were considered.

The auxotrophy of the MaP colonies was verified by means of inoculating conidia in Petri dishes containing solid Minimum Medium (MM) (24), and incubated at $25^{\circ} \mathrm{C}$ for 12 days. The dishes were marked in four diameters of $2.25 \mathrm{~cm}$, to estimate the percentage growth. At the end of this period, conidia which had not formed colonies, were transferred to Petri dishes containing solid MM to which was added, separately, hydrolyzed casein, a solution of yeast nucleic acid, and a solution of vitamins, in order to gain specific knowledge of the nutritional deficiency.

A prior synchronization of conidia (10) was undertaken to analyze germination, thereby obtaining 
conidia of the same age and physiological state. Conidia of the MaP and wild P157 colonies, arising from the synchronization process were put in test tubes containing $9 \mathrm{ml}$ of liquid MM in a concentration of $10^{6}$ conidia/ $\mathrm{ml}$. Aliquots of the medium were with drawn at intervals of one hour, and observed under the light microscope. The percentage of germination was calculated by observing after $12 \mathrm{~h}$ the presence or absence of germination tubes on 500 conidia using a Neubauer Chamber.

Turkey's test was employed to compare the mean growth of the different colonies.

\section{RESULTS AND DISCUSSION}

The results obtained as to the survival in gamma radiation, of conidia of the $\mathrm{P} 157$ strain of $\boldsymbol{M}$. anisopliae var. anisopliae, were used to construct a survival curve (Figure 1). The extrapolated dose to get a 5\% survival was 390 Gy.

Figure 1 - Conidia survival curve of the $\mathrm{P}^{\prime} 57$ strain of $\boldsymbol{M}$. anisopliae var. anisopliae submitted to gamma radiation

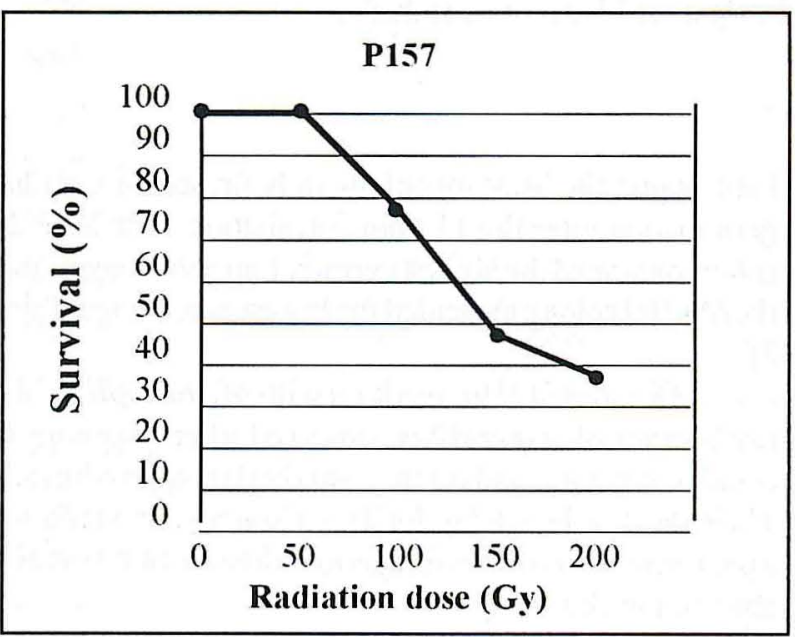

After exposing the conidia suspension to a $390 \mathrm{~Gy}$ dosis , 36 colonies were obtained. The colonies showed that the morphology of the hiphae. conidiphores and conidia were preserved. Among these. 5 showed morphological alteration in colour: 4 colonies a yellow colour (MaP 03, MaP 25, MaP 27, MaP 29) and one a white colour (MaP 17).

Of the 36 colonies obtained after treatment/dose with gamma radiation, 26 colonies showed a mycelial growth in diameter, significantly different from the wild strain according to the data appearing in Table 1.

Only one colony, MaP 28, showed auxotrophy and

\section{Table 1}

Mean mycelial growth (diameter) of MaP colonies of $M$. anisopliae var. anisopliae on the 12th day of growth on solid MC, at $25^{\circ} \mathrm{C}$.

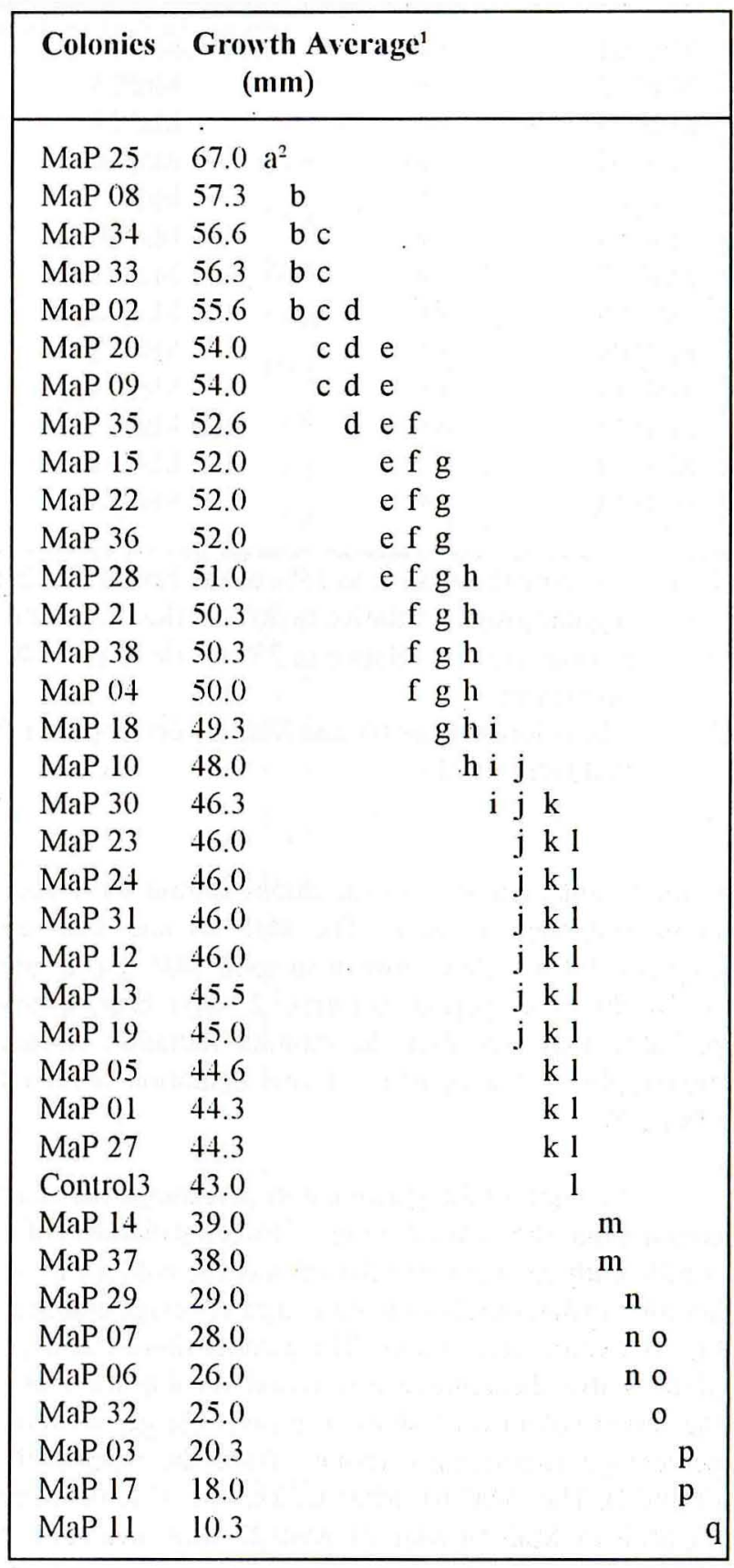

1 Average of three samples.

2 Values followed by the same letter are not statistically different at the $5 \%$ level of probability, according to the Tukey's test.

3 Wild strain, P157. 
Table 2

Growth of MaP colonies of $M$. anisopliae var. anisopliae on the 12 th day of incubation on solid $\mathrm{MM}$, at $25^{\circ} \mathrm{C}$.

\begin{tabular}{|c|c|c|c|c|c|}
\hline Colonies & Growth $^{1}$ & Colonies & Growth & Colonies & Growth \\
\hline MaP 01 & ++ & MaPl4 & ++ & MaP29 & + \\
\hline MaP 02 & ++ & MaP15 & +++ & MaP30 & ++ \\
\hline MaP 03² & -- & MaP17 & + & MaP31 & ++ \\
\hline $\mathrm{MaP} 04$ & +++ & MaP18 & ++ & MaP32 & ++ \\
\hline MaP 05 & ++ & MaP19 & ++ & MaP33 & +++ \\
\hline MaP 06 & ++ & MaP20 & ++ & MaP34 & ++ \\
\hline MaP 07 & ++ & MaP21 & +++ & MaP35 & ++ \\
\hline MaP 08 & ++ & MaP22 & ++ & MaP36 & +++ \\
\hline MaP 09 & ++ & MaP23 & ++ & MaP37 & ++ \\
\hline MaP 10 & ++ & MaP24 & ++ & MaP38 & ++ \\
\hline MaP 11 & ++ & $\mathrm{MaP} 25^{2}$ & -- & Control $^{3}$ & +++ \\
\hline MaP 12 & + & MaP27 & + & & \\
\hline MaP 13 & ++ & MaP28 & -- & & \\
\hline \multicolumn{6}{|c|}{$1+$ low growth. relative to $25 \%$ of the Petri dish diameter. } \\
\hline \multicolumn{6}{|c|}{ ++ regular growth, relative to $50 \%$ of the Petri dish diameter. } \\
\hline \multicolumn{6}{|c|}{+++ normal growth, relative to $75 \%$ of the Petri dish diameter. } \\
\hline \multicolumn{6}{|l|}{2 The } \\
\hline \multicolumn{6}{|c|}{$3 \quad$ Wild strain, P157. } \\
\hline
\end{tabular}

in the complementary tests the colony showed deficiency in paraminobenzoic acid. The MaP 03 and MaP 25 colonies did not show growth in solid MM during the twelve days trial period, but grew 25 days later, which probably indicates that the gamma radiation caused auxotrophy and a reversal of this condition occurred (Table 2).

To analyze the germination percentage the MaP colonies that showed an average of mycelial diameter of a significantly greater value than that of the wild strain, in addition to the some colonies having an average diameter of lesser value were chosen. The germination percentage of the analyzed colonies is to be found in Table 3 . Among the tested colonies, 17 showed an average germination percentage significantly minor from the wild strain (Table 4). The MaP (01. MaP (2), MaP (0). MaP (05. MaP 13, MaP 15, MaP 19, MaP 21, MaP 22, MaP 36 and MaP 38 colonies, showed an average germination percentage. after 12 hours incubation, significantly greater than that of the wild strain. Three colonies. MaP (22, MaP 21 e MaP 36 , began germination of the conidia aftcr a $6 \mathrm{~h}$ incubation; the colonies MaP (06, MaP 14, MaP 22, MaP 30, MaP 32 and MaP 37 after 8 hour: the colonies MaP 08 . MaP 11, MaP 20, MaP 33, MaP 34 and MaP 35 after 9 hour; while the MaP 09 colony only presented conidial germination after the 11 hour incubation. The MaP 21 colony presented the highest germination percentage while the MaP 09 colony presented the lowest percentage(Table 3).

Okino et al.(19), working with M. anisopliae and two species of Aspergillus, observed after exposure of conidia to gamma radiation, a survival of approximately $1 \%$ in the dose of $348 \mathrm{~Gy}$ for $\boldsymbol{M}$. anisopliae, and reported a great sensibility of this fungus to radiation, that was also observed in this study.

Luna-Alves Lima (12), points out that different chemical and physical agents are used in the induction of mutation in organisms, while gamma radiation is little used as a mutagenic agent in entomopathogenic fungi. One of the most widely used physical agents for induction of mutation in filamentous fungi is ultraviolet light (14, 33,37 ). In the improvement programmes for fungi used in biolocal control, ultraviolet light is also used more frequently due to the ease of manipulation. Azevedo (4), points that gamma radiation can be considered as an excellent mutagenic inductor in some cases.

The induction of morphological mutations in filamentous fungi may vary in frequency depending on the 
Table 3

Conidial germination percentage of MaP colonies of $M$. anisopliae var. anisopliae, on liquid MM, at $25^{\circ} \mathrm{C}$.

\begin{tabular}{|c|c|c|c|c|c|c|c|c|}
\hline \multirow[b]{3}{*}{ Colonies } & \multicolumn{8}{|c|}{ Germination percentage $^{1}$} \\
\hline & \multicolumn{8}{|c|}{ Incubation period (hours) } \\
\hline & 5 & 6 & 7 & 8 & 9 & 10 & 11 & 12 \\
\hline Control 2 & - & - & 1.4 & 4.0 & 11.8 & 15.8 & 37.4 & 53.6 \\
\hline MaP 01 & - & - & 2.2 & 4.6 & 12.4 & 17.4 & 39.2 & 60.2 \\
\hline $\mathrm{MaP} 02$ & - & 1.2 & 3.0 & 7.6 & 12.4 & 25.8 & 35.8 & 59.0 \\
\hline MaP (04 & - & - & 4.2 & 10.0 & 27.0 & 33.8 & 36.8 & 61.0 \\
\hline MaP 05 & - & - & 3.0 & 5.8 & 12.0 & 19.2 & 40.2 & 59.8 \\
\hline MaP 06 & - & - & - & 2.2 & 6.4 & 11.8 & 15.2 & 36.2 \\
\hline MaP 07 & - & - & 1.0 & 3.6 & 10.2 & 14.4 & 38.6 & 48.6 \\
\hline MaP 08 & - & - & - & - & 6.0 & 11.8 & 15.8 & 38.0 \\
\hline MaP 09 & - & - & - & - & - & - & 2.6 & 5.8 \\
\hline MaP 10 & - & - & $2 .+$ & 5.0 & 17.0 & 24.0 & 39.0 & 50.8 \\
\hline MaP 11 & - & - & - & - & 3.4 & 5.0 & 12.2 & 18.4 \\
\hline MaP 13 & - & - & 8.4 & 18.8 & 32.6 & 40.4 & 51.8 & 60.6 \\
\hline MaP 14 & - & - & - & 1.2 & 3.2 & 11.0 & 15.8 & 35.2 \\
\hline MaP 15 & - & - & 3.6 & 11.8 & $2+.()$ & 52.4 & 67.8 & 71.2 \\
\hline MaP 18 & - & - & 3.2 & 6.0 & 12.0 & 18.4 & 26.2 & 33.4 \\
\hline MaP 19 & - & - & 7.8 & 17.6 & 31.8 & 38.4 & 49.2 & 58.4 \\
\hline MaP 20 & - & - & - & - & 6.0 & 19.0 & 29.6 & 38.2 \\
\hline MaP 21 & - & 5.6 & 12.8 & 23.8 & 31.4 & 50.2 & 63.2 & 71.6 \\
\hline MaP 22 & - & - & - & 6.2 & 21.0 & 32.0 & 53.0 & 64.6 \\
\hline MaP 23 & - & - & 5.4 & 9.8 & 16.0 & 18.6 & 28.2 & 34.4 \\
\hline MaP 24 & - & - & 5.8 & 9.2 & 15.8 & 19.6 & 30.2 & 36.6 \\
\hline MaP 30 & - & - & - & 1.8 & 4.2 & 20.8 & 3.4 & 37.8 \\
\hline MaP 31 & - & - & 4.8 & 8.6 & 15.6 & 19.0 & 26.0 & 33.2 \\
\hline MaP 32 & - & - & - & 1.2 & 4.4 & 7.8 & 12.2 & 27.2 \\
\hline MaP 33 & - & - & - & - & 4.6 & 13.0 & $2+.6$ & 41.8 \\
\hline MaP 34 & - & - & - & - & 3.8 & 11.8 & 18.2 & 35.2 \\
\hline MaP 35 & - & - & - & - & 7.8 & 15.0 & 33.8 & 53.4 \\
\hline MaP 36 & - & 6.1 & 14.0 & 18.0 & 28.0 & 46.2 & 55.0 & 67.2 \\
\hline MaP 37 & - & - & - & 1.8 & 4.01 & 2.21 & 6.8 & 36.8 \\
\hline MaP 38 & - & - & 13.6 & 24.4 & 31.8 & 49.2 & 53.8 & 67.8 \\
\hline
\end{tabular}

1 Counting of 500 germinated and ungerminated conidia

2 Wild strain, P157 
Table 4

Conidial germination average of MaP colonies of $\boldsymbol{M}$. anisopliae var. anisopliae on the 12 th hour, on liquid MiM, at $25^{\circ} \mathrm{C}$.

\begin{tabular}{|c|c|c|c|c|}
\hline Colonies & Grov & $\begin{array}{l}\text { th Average }{ }^{1} \\
\text { im) }\end{array}$ & & \\
\hline MaP 21 & 71.5 & $a^{2}$ & & \\
\hline MaP 15 & 71.1 & a & & \\
\hline MaP 38 & 68.1 & $a b$ & & \\
\hline MaP 36 & 67.1 & $a b c$ & & \\
\hline MaP 22 & 64.5 & $\mathrm{~b} c \mathrm{~d}$ & & \\
\hline MaP 04 & 61.1 & $\mathrm{c} \mathrm{d} \mathrm{e}$ & & \\
\hline MaP 13 & 60.6 & $\mathrm{~d} \mathrm{c}$ & & \\
\hline MaP 01 & 60.2 & $\mathrm{~d} \mathrm{e}$ & & \\
\hline MaP 05 & 59.7 & $\mathrm{de}$ & & \\
\hline MaP 02 & 59.0 & $d$ e $f$ & & \\
\hline MaP 19 & 58.4 & e $f$ & & \\
\hline Control $^{3}$ & 53.6 & $\mathrm{f}$ & & \\
\hline MaP 35 & 53.3 & $\mathrm{f}$ & & \\
\hline MaP 10 & 50.7 & & 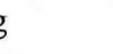 & \\
\hline MaP 07 & 48.5 & & g & \\
\hline MaP 33 & 41.7 & & $\mathrm{~h}$ & \\
\hline MaP 20 & 38.1 & & h i & \\
\hline MaP 08 & 38.0 & & h i & \\
\hline MaP 30 & 37.8 & & h i & \\
\hline MaP 37 & 36.8 & & h i & \\
\hline MaP 06 & 36.2 & & $\mathrm{~h} \mathrm{i}$ & \\
\hline MaP 24 & 36.1 & & $\mathrm{~h} \mathrm{i}$ & \\
\hline MaP 14 & 35.1 & & $\mathrm{i}$ & \\
\hline MaP 34 & 35.1 & & $\mathrm{i}$ & \\
\hline MaP 23 & 34.3 & & $\mathrm{i}$ & \\
\hline MaP 18 & 33.4 & & $\mathrm{i}$ & \\
\hline MaP 31 & 33.2 & & $\mathrm{i} \mathrm{j}$ & \\
\hline MaP 32 & 27.1 & & $\mathrm{j}$ & \\
\hline MaP 11 & 18.3 & & & $\mathrm{k}$ \\
\hline MaP 09 & 5.7. & & & 1 \\
\hline
\end{tabular}

1 Average of three samples.

2 Values followed by the same letter are not statistically different at the $5 \%$ level of probability, according to the

Tukey's test.

3 Wild strain, P157.

type of mutagenic agent used for induction $(12,21,22)$. Using UV as a mutation inductor in Beauveria bassiana, Paccola-Meirelles (21), points out that it was not obtained any stable morphological mutant, while it were obtained 22 morphological mutants to colour by using gamma radiation as an agent.

Morphological mutants of entomopathogenic fungi, obtained by artificial processes, are of the highest importance, bccause they may facilitatc the recognition of recombinants in crossings via the parasexual cycle which increases their possibilities of being in a single genome, genes potentially favourable to entomopathogenic action (12). Oliveira et al .(20), obtained morphological mutants to colour of conidia in $\boldsymbol{M}$. anisopliae var. minus and $\boldsymbol{M}$. anisopliae var.majus, using as mutagenic agents 8-metoxipsolarein associated with long UV.

Luna-Alves Lima (12), working with $\boldsymbol{M}$. anisopliae var. anisopliae obtained by using Ultraviolet light 14 simple auxotrophic mutants and 5 doubles; PaccolaMeirelles (21). obained after treatment of conidia of an isolate of Beauveria bassiana with gamma radiation, 5 simple mutants and 3 with double auxotrophic marks.

One of the detcrmining factors in the pathogenicity of entomopathogenic fungi is the germination of conidia, this being the first step for host infection (16). Samuels et al. (28), stated that parameters like germination speed and growth are correlated with the high virulence of some strains of $\boldsymbol{M}$. anisopliae for Nilaparvata lugens. The age of the colony can be considered as an interaction factor in a conidial germination. Hall et al. (8), in a comparative analysis of different species of entomopathogenic fungi claim that conidia coming from young cultures show more rapid germination than those of old cultures. In this study the synchronization of the conidia from the wild strain and from the MaP colonies was reached in such a way that the conidia used in the germination trial possessed the same physilogical conditions, thus climinating variation due to the age of the conidia:

It was observed that the MaP 15, MaP 21, MaP 33 and MaP 36 colony, showed accordingly a high germination percentage, good growth in MM and $\mathrm{MC}$ and in addition to this, MaP 21 began germination well in advance. Considering that characteristics like high percentage and specd of germination, apart from good mycelial growth, are desirable in entomopathogenic fungi, the colonies which showed such characteristics may be promising for use in genetic crossing aiming the incorporation of these characteristics into strains with recognized good performance in biological control.

The biotypes obtained in this study need further studies to analyze other changes arising from the cxposure to gamma radiation which may well contribute to the knowledge of the genctic bases associated with the most appropriate phenotypes for biological control programmes. 


\section{REFERENCES}

1. Aguiar, N. T. O. de. (1991). Variabilidade em linhagens de Metarhizium anisopliae var. anisopliae (Metsch) Sorokin quanto a Germinaçâo de Conídios, Conteúdo Protéico e Atividade Enzimática, Tese de Doutorado Universidade Estadual de Campinas.

2. Alves, S. B. (1986). Patologia Geral. In. S. B. ALVES ed. Controle Microbiano de Insetos. Sâo Paulo, Editora Manole.

3. - (1992). Perspectivas para utilização de fungos entomopatogénicos no controle de pragas no Brasil. Pesquisa Agropecuária Brasileira, 27: 77-86.

4.---allonomento genético de fungos utilizados no controle biológico de doenças de plantas. IN: W. Bettiol. Controle Biológico de Plantas. Brasilia.

5.--- Costa, S. O. P. (1973). Exercicios práticos de genética. Sâo Paulo. Editora Nacional EDUSP.

6.Bridge, P. D.; Willians, M. A. J.; Prior, C.; Patterson, R. R. M. (1993). Morphological, biochemical and molecular characteristics of Metarhizium anisopliae and $M$. flavoviride. Journal of General Microbiology 139:1163-1169

7. Fernandes, P. M.; Alves, S. B.(1992). Seleçâo de Isolados de Beaı veria bassiana (Bals.) Vuill. e Metarhizium anisopliae (Metsch.) Sorokin para Controle de Cornitermis cumulans (Kollar, 1832) (Isoptera Termitidae). Anais da Sociedade Entomológica do Brasil 21:319-329.

8. Hall, R. A.; Papierok, B.; Lopez, V. F.(1994). Influence of culture age rate of conidiospore germination in four deuteromycetous entomogenous fungi. Mycological Research 98:763-768.

9.Hassan, A. E. M.; Dillon, R. J.; Charnley, A. K. (1989). Influence of accelerated germination of conidia on the pathogenicity of Metarhizium anisopliae for Manduca sexta. Journal of Invertebrate Pathology 7:277279.

10. Law, D. J.; Timberlake, W. E. (1980). Developmental regulation of lacase levels in Aspergillus nidulans. Jounal of Bacteriology 144: 509-517.

11. Li, D. P.; Heldon, D. G. (1995). Effects of nutrients on colony formation, growth and sporulation of Metarhizium anisopliae (Deuteromycotina: Hyphomycetes). Journal of Invertebrate Pathology 65:253-260.

12. Luna-Alves Lima E, A. (1985). Caracteristicas citológicas e genéticas de linhagens selvagem, mutantes e diploides de Metarhizium anisopliae (Metsch.) Sorokin. Tese de Doutorado, Universidade Federal do Rio de Janeiro, Rio de Janeiro, Brazil.

13. Martins, J. F. S.; Lima, M. G. A. (1994). Fungos entomopatogénicos no controle do percevejo do colmo do arroz Tibraca limbativentris Stal. viruléncia de isolados de Metarhizium anisopline (Metsch.) Sorokin e Beauveria bassiana (Bals.) Vuill. Anais da Sociedade Entomológica do Brasil 23:40-44.

14. Messias, C. L.; Azevedo, J. L.; Conti, E.; Souza, II. M. (1978) Aspectos Biológico e Induçào de Mutantes em Metarhizium anisopliae. Resumo do $3^{\circ}$ Congresso Latino Americano de Entomologia e $5^{\circ}$ Congresso Brasileiro de Entomologia, Bahia
15. McCammon, S. A.; Rath, A. C. (1994). Separation of Metarhizium anisopliae strains by temperature dependent germination rate. Mycological Research 98:1253-1257

16. Milner, R. J.; Huppatz, R. J.; Swaris, S. C. (1991). A new method for assessment of germination of Metarhizium conidia. Journal of Invertebrate Pathology 57:121-123.

17. Moorhouse, E. R.; Gillespie, A. T.; Charneley, A. K.(1993). Selection of virulent and persistent Metarhizium anisopliae isolated to control black vine weevil (Otiorhynchus sulcatus) larvae on glasshouse Begonia. Journal of Invertebrate Pathology 62: 47-52

18. Morley-Davies, J.; Moore, D.; Prior, C. (1996). Screening of Metarhizium and Beauveria ssp. conidia with exposure to simulated sunlight and a range of temperatures. Mycological Research 100:31-38

19. Okino, L. A.; Silva, J. C.; Santos, A. L. L., Messias, C. L.; Azevedo, J. L. (1978). Detenninaçâo da sobrevivéncia de Metarhizium anisopliae e de duas espécies de Aspergillus à radiaçâo gama. "O Solo" 70:32-36.

20. Oliveira, C. D.; Siqueira-Jr., J. P.; Nakamura, P. H.; Silva, J. C. (1994). Pathogenicity of Morphological Mutantes and Wild-typres of Metarhizium anisopliae (Metsch.) var. majus and minus against Anthonomus grandis Boheman. Anais Sociedade Entomológica do Brasil 23:425-430.

21. Paccola-Meirelles, L. D. (1988). Variabilidade e Recombinaçâo genética no Deuteromiceto Beauveria bassiana (Bals.) Vuill. Tese de Doutorado, Escola Superior de Agricultura "Luiz de Queiroz",Piracicaba.

22. Papavizas, G. C.; Lewis, J. A.; Abd-El-Moyty, T. H. (1982) Evaluation of new biotypes of Trichoderma harzianum of tolerance of Benonyl and enhanced biocontrol capabilities. Phytopathology, ST. Paul, 72: $126-132$

23. Paterson, J. C.; Charley, A. Y.; Cooper, R. M.; Clarkson, J. M. (1994). Specific induction of a cuticle-degrading protease of the insect pathogenic fungus Metarhizium anisopliae. Microbiology (Reading) 140:185-189

24. Pontecorvo, G.; Roper, J. A.; Hemons, L. M.; Mac Donald, K. D.; Button, A. N. J. (1953). The genetics of Aspergillus nidulans. Advances Genetics 5:141

25. Quintela, E. D.; Wraight, S. P.; Quinderé, M. A. W.; Roberts, D. W. (1994). Aplicaçào de conidios de Beauveria bassiana (Bals.) Vuill. e Metarhizium anisopliae (Metsch.) Sor. para controle de larvas de Chalchodermus bimaculatus Bor. (Coleoptera: Curculionidae) no solo. Anais da Sociedade Entomológica do Brasil 23:367-377

26. Riba, G.; Azevedo, J. L.; Messias, C.L.; Silveira, W.D.; Tuvesson, R. (1985). Studies of the inheritance of virulence in the entomopathogenic fungus Metarhizium anisopliae. Journal of Invertebrate Pathology 46:2025

27. Shadduck, J. A ; Roberts, D. W.; Lause, S. (1982). Mammalian safety test of Metarhizium anisopliae preliminary results. Environmental Entomology, 11:189-192

28. Samuels, K. Z.; Heale, J. B.; Lewellyn, M. (1989). Characte- 
ristics relating to the pathogenicity of Metarhizium anisopliae toward Nilaparvata lugens. Journal of Invertebrate Pathology 53:25-31

29. Silva, J. C., Messias, C. L. (1986). Virulence of mutants and revertants of Metarhizium anisopliae var. anisopliae toward Rhodnius prolixus. Journal of Invertebrate Pathology 48:368-374

30. Silveira, N. S. S. D.; Campos-Takaki, G. M. D.; Menezes, M. (1993). Effect of vinasse on germination of Metarhizium anisopliae (Metsch.) Sorokin "in vitro" and in the soil. Revista de Micologia 24 :140143

31. St. Leger, R. S.; Roberts, D. W.; Staples, R. C. (1991). Genetics differences in allozymes and in dormation of infection structures among isolates of the entomopathogenic fungus Metarhizium anisopliae. Journal of Invertebrate Pathology 60:89-101

32. Sundarababu, P. C.; Balasubramanian, M. Jayaraj, S. (1984). Studies on the pathogeniticy of Metarhizium anisopliae (Metschnikoff) Sorokin var. major Tulloch in Orictes rhinocerus (L.) Panil Nadu Agricultural University (Coimbatore-3)
33. Tsai, Y'. S.; Kao, C. W.; Hou, R. F.; Kao, S. S. (1993). Screening of fungicide resistant isolates of Metarhizium anisopliae var. anisopliae. Chinese Journal of Entomology 13:45-57

34. Veiga, A. F. S. L. (1979).O fungo entomógeno Metarhizium anisopliae (Metsch.) Sorokin como opçâo para o controle biológico das cigarrinhas-das pastagens (Homoptera: Cercopidae) no Estado dePernambuco. Boletim do Grupo de Pesquisadores de Controle Biológico 1:3-4.

35. Vega, M. E. (1990). Aspectos Genéticos da Parameiose Via Fusâo de Protoplastos em Metarhizium anisopliae (Metsch.) Sorokin. Tese de Mestrado, Escola Superior de Agricultura 'Luiz de Queiroz", Piracicaba, SP.

36. Wilson, M.; Lindow, S. E. (1993). Release of Recombinant Microorganisms. Annual Reviews of Microbiology 47:913-944

37. Yokoyamia, T.; Fujikata, M.;Fujiie, A. (1993). Improvement of Metarhizium anisopliae (Metschnikoff) of Anomala cuprea Hope (Coleoptera: Scarabaeidae by ultraviolet irradiation protoplasts. Applied Entomology and Zoology 28: 451-461. 